Samira Dedić ${ }^{1}$

Amra Nuhanović ${ }^{2}$

Jasenka Đulić3

\title{
RESEARCH ON THE IMPORTANCE OF PERFORMANCE OF BUSINESS EXCELLENCE OF HOTEL COMPANIES IN THE TIME OF GLOBALIZATION AND REGIONALIZATION
}

\begin{abstract}
The focal point of the research in this paper is based on examining and evaluating the role and importance of performance of business excellence in the hotel industry in the time of globalization and regionalization. The research conducted in this paper included the views of hotel managers related to each performance of business excellence in Bosnia and Herzegovina. The situation with the application of the concept of business excellence in the practice of hotel companies in $B \& H$ is not particularly favourable, since this issue has not been addressed at all. Although we can see progress in improving the quality of service provision in B\&H hotels, the concept of business excellence has not been sufficiently researched, and therefore not represented in the field of hotel business. Taking into account the previous, the authors came to the conclusion that everything points to the need for adoption and business according to the concept of business excellence, and that its application is necessary to ensure good business results, and thus achieve competitive advantage of each hotel company. Within the elaboration of the theoretical starting points of the observed problem, the methods of analysis and synthesis, i.e. induction and deduction, were used, with the necessity of using a systematic approach in the research. In the empirical part of the research, statistical methods of univariate analysis (descriptive statistical analysis), bivariate analysis and multivariate analysis were used. The collected data were processed with the help of SPSS Statistics 20.0
\end{abstract}

Keywords: globalization, regionalization, performance, business excellence, hotel enterprises.

JEL: $F$ 66, C 19, A 12

$1 \mathrm{PhD}$, Associate professor University of Tuzla, Faculty of Economics, Univerzitetska 8, $75000 \mathrm{Tu}-$ zla, E-mail: samira.dedic@untz.ba

$2 \mathrm{PhD}$, Associate professor University of Tuzla, Faculty of Economics Univerzitetska 8, 75000 Tuzla E-mail: amra.nuhanovic@untz.ba

3 Postgraduate student Rudnička b.b., 75300 Lukavac E-mail: jasenka.djulic@hotmail.com 


\section{INTRODUCTION}

As the environment in which hotel companies operate is very turbulent, dynamic and uncertain, survival in the market and achieving business success are increasingly becoming an imperative. In the last few years, there have been a number of trends in the world market, which have certain impacts on the entire hotel business. The implementation of the concept of business excellence is gaining a crucial role in all this. The application of the concept of business excellence is more recent, but with a tendency of increasing representation in the hotel sector. Today, with the increase of competition in the market, business excellence has become an important area of research, and has been identified as one of the leading factors in achieving comparative advantages over competing hotel companies [Tsai et al (2015), pp. 522]

In the time of globalization and regionalization of the world market, it is crucial to base hotel business on business excellence as a concept of business management, since the process of implementing this concept can be one of the fundamental pillars of hotel development in Bosnia and Herzegovina (B\&H).

\section{Previous research}

Globalization as a concept began to appear at the end of the 20th century. Today, we encounter this word every day, both in private and business segments of life. The very term globalization is derived from the word "global" which means totality, and accordingly we can say that "globalism" is a way of looking at events in the global. [McKinsely Global Institute, (2019), pp. 4]. Globalization would thus imply a social process that strives for the comprehensiveness and uniqueness of the world [Turek, (1999), pp. 159]. As an idea, it refers to the "reduction" of the world, but also to the strengthening of awareness of the world as a whole [Milardović, (1998), pp. 271]. "Shrinking" the world has raised awareness of the interconnectedness and interdependence of its various parts. There is an abandonment of old and acceptance of new, broader identities. [Njavro, (1999), pp. 236]. Globalization can be argued to be one of the consequences of the development of science, modern technology, market economy, democracy and has enabled the free movement of capital, goods, information and people through the expansion and abolition of borders. In which the threads of interdependence - technological, political, economic, and ecological intertwine at tremendous speed, nullifying geographical distances, universalizing the democratic form of the government, and increasing wealth. It is, therefore, a process that leads to social progress in all its aspects: economic-political, technological and cultural-scientific. Globalization processes are increasingly affecting segments of the tourism market, where the hotel industry is particularly prominent, which has caused the initiation of the process of regionalization of hotels at all levels. 
The functioning of the tourist market in the conditions of globalization requires the construction of an international business infrastructure, which is represented by numerous international institutions and agreements. Properly formed international infrastructure provides a favourable climate for regionalization and globalization, overall control and insight into the economic, financial and political aspects of business [Youcheng Yu et al (2015), pp.116] Multinational hotel corporations' play an important role in shaping business conditions, and it is for this reason that horizontal regionalization comes to the fore. It is necessary to point out that on a global scale; a large part of hotel and tourism organizations is conceived on the principle of small family hotels and small and medium-sized hotel companies, according to the concept of a limited liability company. Large hotel and tourism corporations are usually organized as joint stock companies. Modern tendencies in the development of hotel organization and entrepreneurship take place under the influence of scientific and technological achievements, market economy and modern trends in management.

For the hotel industry, globalization has brought with it consolidation, i.e. merging and merging smaller hotels into larger hotel chains. The internationalization of business leads to business connections between bidders, in order to improve business efficiency and achieve the highest possible profit. All integrated holders of the tourist offer strive to satisfy the tourist demand to the maximum, in order to make a possible profit from this form of business. The purpose of integration is to create a whole in which a certain degree of coordination is established among the many entities involved in the provision of complex tourism services. It is an inevitable fact that nowadays, the hotel industry is experiencing growing pressure - on the one hand increasingly demanding guests, and on the other hand, strong competition, as a result of consolidation in the industry. [Newaidomski (2015), pp 5]. Maintaining a successful business of a hotel company today is based on building customer loyalty by creating services that are simple, but also tailored to each user individually. The ability to create such an environment in a hotel is determined by the knowledge and application of information and communication technologies that can enrich the user experience like never before. Today, it is considered a global trend for small and medium-sized hotels in the world to introduce advanced technologies based on a single communication infrastructure - with the aim of laying the foundation for the development of customer-friendly services, increasing customer loyalty and increasing sales revenue. For new hotels, all this is not a problem, but existing hotels often still face the challenge of smart reconstruction and renovation. Otherwise, they are threatened with remaining behind the development of the industry.

By investing in information and communication technologies, hotels get not only new types of services and opportunities for additional earnings, but also opportunities to increase the category, and thus of course the price of services. 
In the hotel industry, globalization is most pronounced in the efforts of hotel companies to apply international business standards and to obtain the status of a global economic entity. [Mihajlović Krželj, (2015), pp.108] International hotel chains, i.e. their origin and development, represent the initial capsule, i.e. the driving motive, which paved the way for the expansion and globalization of the hotel industry across the planet. In a very short time, hotel chains became synonymous with the hotel industry and also contributed to its opening and popularization. Thanks to its growth and development and increasing territorial distribution in every part of the planet, hotel chains have directly influenced the diversification of the most modern industry and it is estimated that in the very near future it will become one of the most profitable activities.

Global marketing has a cosmopolitan aspect, as it focuses on meeting the needs of people around the world. Its basic postulate is Ted Bates' phrase: "Think globally, work locally."[Zaitseva et al (2016), pp. 7178]. We can say that it is more adequate to talk about globalization and localization, as alternative strategic approaches, which can be followed when planning and implementing international marketing activities. The global approach seeks similarities in products, markets, marketing and propaganda messages, while the multifocal approach ignores these similarities, making differences between markets. Taking the example of hotel companies that compete in the international market or those that are just planning to do so, they are increasingly facing one enemy - time. A company that appears on the global market before someone else with a new product, service, new technology or significant innovation, makes a decisive impact in maximizing profits. Of course, this is not always possible in everything, but that is exactly what the new strategy consists of, its realistic side: it cannot be acquired on the market through others - on the entire front, but to be realized in its strategic sectors. For such a strategy and philosophy, the reward is definitely the realization of significant profits and advantages over competitors, which is manifested in the speed of market presence, technology and its productivity. Achieving business excellence of a hotel company in the hotel industry is the result of all business functions. In order to establish a stable market position and achieve development goals, it is necessary to intensify marketing efforts. Namely, hotels must set themselves the preconditions for improving the quality of business, which is based on the permanent improvement of labour productivity and knowledge, as well as responding to the requirements of service users. The benefits of hotel companies involved in the process of globalization, which keeps pace with the times, can be reduced to the following: 1) ensuring the long-term success of the hotel company; 2) regionalization expands the spectrum of hotel services; 3 ) all constant improvements become a reality; 4) observing changes and reacting to them, creativity, innovation and adaptability increase; 5) attracting people who want to succeed and learn, and 
keeping them in a hotel company; and 6) ensure that people are equipped to meet the current and future needs of the hotel business.[Zaitseva et al (2016), pp. 7178]

Finally, we can say that by applying globalization and regionalization of business excellence in the hotel industry, benefits are achieved, both for users of hotel services and for employees themselves, that is, the goal of business excellence is achieved. Recall that, business excellence is nothing but a way of doing business that allows organizations to achieve balanced satisfaction of all stakeholders (customers, employees, society and shareholders).

Business excellence performance is the way in which an organization or company creates and develops a differentiated set of activities and capabilities that create / generate optimal products or services. [Žilić, (2011), pp. 88]. In what follows, we will briefly explain each of the business excellence performances used in this research.

Hotel offer (guest value). According to Kandampully (2007), hotel employees should observe their guests from the point of view of customer / guest lawyers. In this way, employees express their role in relationships when providing a service or product in ways of personal connection with customers or guests. This strong commitment of employees towards customers or guests encourages and can ensure the high quality of services of the hotel company even in the conditions of the greatest economic crises. [Kandampully, (2007), pp. 128]

Staff education. In the hotel industry, which employs over 70 million people, Walker (2009) points out that efficient planning cannot be done without human resources. Human resources attract, select, orient, train, teach, advise, mentor and develop the efficiency of evaluating, implementing, supporting and ensuring the quality staff in hotel companies. Based on a 2008 survey, based on a sample of 243 managers, and identified a set of problems that hinder the effectiveness of leaders. More than $60 \%$ of managers from six regions of the world stated that human resources have problems in the areas: attraction, retention, training and morale. In addition to them, there were other problems, related to issues in the field of economy and environment, understanding the needs of users, operating costs and strategic thinking about the competitive environment.

Process and resource management. Hotel services consist of a series of processes, which are managed and which need to be constantly maintained and improved, with the aim of eliminating shortcomings and mistakes, in order for the guest to be as satisfied and enthusiastic as possible. For all processes in a hotel, it is crucial that they are efficient and effective.

To achieve business excellence in the strategic management of a hotel business, it is necessary first of all to know its processes. 
Mass customization is a holistic approach to bringing products or services to market, keeping the customer at the centre of every aspect of the organization. [Moutinho, (2005), pp. 256]

Quality assurance. For a long time now, the world has been dominated by the trend of globalization, which is necessarily associated with liberalization, but also the acceleration of world economic flows. In the last decade, there has been an extremely sharp expansion of world trade, which has begun to take place according to new rules. With the removal of restrictive laws and regulations, the success of economic entities, and thus hotel companies, has become primarily dependent on their ability to ensure a high level of quality of their services.

Social responsibility. Social responsibility enables companies to take a proactive attitude in the functioning of society, whereby social responsibility refers not only to business ethics but also to social development and the need to improve society. [Enz, (2010), pp. 44.] Corporate social responsibility and its sustainability play a significant role in developing the concept of business excellence. Understanding corporate social responsibility, as an integral part of organizational excellence, responsibility and behaviour towards society and the environment, is extremely important for longterm business success.

Continuous improvement. Quality management in hotel companies is very complex due to the fact that it is necessary not only to ensure a high level of quality of accommodation and food, but also the services provided. This is a difficult task for a hotel company, but also a challenge, as well as with what business organization to achieve the expected results: profit, satisfied workers and partners, satisfied community and most importantly satisfied guest, i.e. consumer of catering services.

Standardization and quality in hotel companies implies standardization at all levels of the hotel company's service program, so that quality can fully support market performance [de Souza Meira et al (2018), pp.2] Therefore, standards in the creation and provision of hotel services are necessary primarily to ensure the quality of services and continuous, effective business.

\section{Research methodology}

Empirical research was conducted on the basis of primary data collection by field research, using the survey method (written examination technique), using a highly structured survey questionnaire as a form for data collection. The survey questionnaire is divided into five parts. The first part contains questions related to the profile of the respondents, and includes socio-demographic indicators, as well as questions related to the workplace in the hotel. 
The second part of the questionnaire included questions related to assessing the importance of performance (dimensions) of business excellence of hotel companies, which means: hotel offer - value for money, staff training, process and resource management, quality assurance, social responsibility and continuous improvement. Third, fourth and five questionnaires related to: 1) assessing the importance of "tourist satisfaction", 2) assessing the importance of implementing various hotel services, 3) assessing the importance of performance indicators of hotel companies. The survey questionnaire used the Likert scale with five levels of agreement, where a score of one indicates that the respondent completely disagrees with the given statement, and a score of five that he completely agrees with.

Primary data were collected by the management of hotel companies from the territory of $\mathrm{B} \& \mathrm{H}$. The survey questionnaire referred to questions about the attitudes of respondents towards the degree of implementation of the concept of business excellence and its impact on the success of hotel operations. The basis for structuring the sample was data from the register of the Indirect Taxation Authority of B\&H (ITA), the Association of Hoteliers and Restaurateurs of B\&H, and the Federal Ministry of Environment and Tourism. Data collection was performed on the basis of a proportional stratified sample, since it belongs to the category of random samples and allows assessing the degree of reliability of conclusions about the investigated parameters. Since these are hotel companies, the categorization criterion used the categorization of hotel facilities, which is determined by the number of stars in hotels. The choice of hotel categorization as a stratification criterion is based on the results of examinations by experts from the Association of Hoteliers and Restaurateurs of B\&H, and the Federal Ministry of Environment and Tourism.

The empirical research was conducted on a sample of hotels of the first and second category, i.e. it included two strata: four and five star hotels. According to the existing data, the total number of such hotels in B\&H is 95 . Since this is a concept of business excellence, this research does not include hotels of lower categories. Data collection was performed in the period from April to August 2015. The fraction, i.e. the rate of selection of hotels in the sample was $45.26 \%$. Thus, the selected hotels were classified according to the number of stars in two strata. The structure of the sample according to the number of stars is presented in Table 1 .

Table 1: Sample size and structure

\begin{tabular}{|c|c|c|c|c|c|c|}
\hline \multirow[b]{2}{*}{ Category } & \multirow{2}{*}{$\begin{array}{l}\text { Number of } \\
\text { asterisks }\end{array}$} & \multicolumn{2}{|c|}{ The basis of choice } & \multicolumn{3}{|c|}{ Sample } \\
\hline & & $\begin{array}{l}\text { Number of } \\
\text { hotels }\end{array}$ & $\%$ & $\%$ & $\begin{array}{c}\text { Number of } \\
\text { hotels }\end{array}$ & $\begin{array}{c}\text { Number of } \\
\text { hotels in sample }\end{array}$ \\
\hline 1 & 5 & 10 & 10,53 & 10,53 & 4,53 & 5 \\
\hline 2 & 4 & 85 & 89,47 & 89,47 & 38,47 & 38 \\
\hline$\sum$ & & 95 & 100,00 & 100,00 & 43 & 43 \\
\hline & factio & choice: $(43 / 95)^{3}$ & $100=0$ & $4526 * 10$ & $=45,26 \%$ & \\
\hline
\end{tabular}


Based on the criteria given in Table 1, the list of hotels is classified into two categories according to the number of stars. A random selection was made for each of the categories individually and thus a list of 43 hotels was formed, i.e. a list of 5 five-star hotels and a list of 38 four-star hotels.

\section{Results and discussion}

In order to establish the impact of business excellence dimensions on business performance indicators of hotel companies in Bosnia and Herzegovina, we first examined and tested the significance of mutual correlations of all observed variables, and then analysed the data relying on simultaneous multiple regression analysis. The Pearson correlation coefficient was used as an indicator of the strength and direction of the two phenomena. Based on the conducted correlation analysis, we can conclude that the positive relationship between the dimensions of business excellence, on the one hand, and the performance indicators of hotel companies, on the other hand, has been confirmed, supported by the final summary correlation table.

Table 2: Statistically significant correlations between the dimensions of business excellence and performance indicators of hotel companies from the aspect of hotel managers

\begin{tabular}{|l|c|c|c|c|c|c|}
\hline \multicolumn{7}{|c|}{ Correlations of the observed variables (p<0,05; N=43) } \\
\hline Variables & $\begin{array}{c}\text { hotel offer } \\
\text { - value for } \\
\text { money P1) }\end{array}$ & $\begin{array}{c}\text { staff } \\
\text { training } \\
\text { (P2) }\end{array}$ & $\begin{array}{c}\text { process and } \\
\text { resource } \\
\text { management } \\
\text { (P3) }\end{array}$ & $\begin{array}{c}\text { quality } \\
\text { assurance } \\
\text { (P4) }\end{array}$ & $\begin{array}{c}\text { social } \\
\text { responsibility } \\
\text { (P5) }\end{array}$ & $\begin{array}{c}\text { continuous } \\
\text { improvement } \\
\text { (P6) }\end{array}$ \\
\hline $\begin{array}{l}\text { performance } \\
\text { indicators }\end{array}$ & $0,612 * *$ & $0,551 * *$ & $0,593 * *$ & $0,867 * *$ & $0,667 * *$ & $0,816^{* *}$ \\
\hline
\end{tabular}

Source: author's creation

In order to test the defined hypothesis that there is a statistically significant impact of business excellence dimensions on business performance indicators of hotel companies, we calculated the parameters of the model of simultaneous multiple regression analysis, ANOVA and the necessary beta coefficients. In a simultaneous multiple regression analysis, the predictive power of each independent variable is estimated, that is, it is measured to what extent it would improve a model consisting of a series of independent variables. Multiple regression actually shows how much of the variance of the dependent variable is explained by the variance of the independent variables. The following table shows the parameters of the model of simultaneous multiple regression analysis. 
Table 3: Simultaneous multiple regression analysis model for the dependent variable " hotel business performance indicators"

\begin{tabular}{|r|rr|r|r|r|}
\hline Model & \multicolumn{2}{|c|}{ R } & \multicolumn{1}{|c|}{ R Square } & \multicolumn{1}{c|}{$\begin{array}{c}\text { Adjusted R } \\
\text { Square }\end{array}$} & $\begin{array}{c}\text { Std. Error of the } \\
\text { Estimate }\end{array}$ \\
\hline 1 & &, $885^{\mathrm{a}}$ &, 782 &, 746 &, 25063440 \\
\hline
\end{tabular}

Source: author's creation

The table shows that the coefficient of multiple linear correlation is 0.885 , which suggests that there is a very strong positive linear relationship between the observed variables. A specific indicator of the representativeness of simultaneous multiple regression is the coefficient of multiple determination. The coefficient of multiple determination shows the percentage of variation of the dependent variable which is explained by the combined influence of the independent variables included in the model. It can take values in the interval $[0,1]$. The model is more representative if the coefficient is closer to unity. Based on the parameters in the model, we can conclude that the coefficient of determination $\mathrm{R} 2=0.782$, which means that the selected model of simultaneous multiple regression analysis interpreted $78.2 \%$ of all deviations, which implies the conclusion that the model is very representative. Statistically speaking, it shows what percentage of the variability of the dependent variable is explained by the variability of the independent variables, i.e. in our case this coefficient shows how much of the variance of the dependent variable, processes and resources, social responsibility, staff training and quality assurance (78.2\% dependence of the dependent variable on all six independent variables). Thus, the dimensions of business excellence significantly explain more than two-thirds of the variance of the dependent variable. The analysis of variance showed that the presented model of simultaneous multiple regression analysis was statistically significant, since the value of sig. less than $0.05(\mathrm{p} \approx 0) ; \mathrm{F}(6.36)=21.571$. Thus, the model is suitable for further data processing (Table 4).

Table 4: ANOVA

\begin{tabular}{|c|l|r|r|r|r|r|}
\hline \multicolumn{2}{|c|}{ Model } & Sum of Squares & df & Mean Square & F & Sig. \\
\hline 1 & Regression & 8,130 & 6 & 1,355 & 21,571 &, $000 \mathrm{a}$ \\
& Residual & 2,261 & 36 &, 063 & & \\
& Total & 10,392 & 42 & & & \\
\hline
\end{tabular}

Furthermore, in order to take the most important step in examining the relationship and testing the impact of business excellence dimensions on hotel performance indicators, we conducted a simultaneous multiple regression analysis and calculated the necessary beta coefficients, which will show the importance of each independent variable in forecasting or influencing the dependent variable and the extent to which all independent variables combined explain the variations of the dependent variable. The obtained results are shown in the table below. 
Table 5: Results of simultaneous multiple regression analysis

\begin{tabular}{|c|l|r|r|r|r|r|}
\hline \multirow{2}{*}{\multicolumn{2}{|c|}{ Model B }} & \multicolumn{2}{|c|}{ Unstandardized Coefficients } & $\begin{array}{c}\text { Standardized } \\
\text { Coefficients }\end{array}$ & \multirow{2}{*}{ t } & \multirow{2}{*}{ Sig. } \\
\cline { 2 - 6 } & Std. Error & \multicolumn{1}{|c|}{ Beta } & & & \\
\hline 1 & constant &, 563 &, 491 & & 3,185 &, 003 \\
& Hotel offers &, 664 &, 207 &, 562 & 3,205 &, 000 \\
& Staff training &, 335 &, 099 &, 346 & 3,390 &, 002 \\
& Process and resources &, 490 &, 108 &, 477 & 4,534 &, 000 \\
management & 1,022 &, 332 &, 827 & 3,084 &, 000 \\
& quality assurance &, 586 &, 147 &, 509 & 3,994 &, 000 \\
& Social responsibility &, 916 &, 219 &, 619 & 4,183 &, 000 \\
\hline
\end{tabular}

Source: author's creation

As the beta coefficients define which independent variables have the greatest influence on the variance of hotel business performance indicators, based on the presented standardized beta coefficients, we can conclude that the highest beta coefficient is 0.827 , which is actually the value for variable "quality assurance". As in the previous case, this variable individually contributes the most to the explanation of the dependent variable "performance indicators of hotel companies", followed by the variables "continuous improvement" "hotel offer-value for money" and "social responsibility". Consequently, observing the significance, i.e. $\mathrm{p}$ - value from the previous table, we can conclude that all independent variables have a statistically significant impact on the dependent variable, indicators of business performance of hotel companies. In addition, we can draw the following conclusions: the most important predictor is certainly the dimension of business excellence quality assurance $(\beta=0.827 ; \mathrm{t}=3.084$; $\mathrm{p} \approx 0$ ). Dimension hotel offer - value for money has a statistically significant impact on the performance indicators of hotel enterprises $(\beta=0.562 ; t=3.205 ; p \approx 0)$. The independent variable "education of staff" proved to be somewhat weaker, but still a statistically significant predictor $(\beta=0.346 ; t=3.39 ; p<0.05)$. Important predictors of hotel performance indicators are certainly the variables social responsibility and continuous improvement, while the impact of the independent variable process and resource management on the dependent variable is moderate, but of statistical importance. To summarize, the conducted simultaneous multiple regression analysis showed a statistically significant impact of all six dimensions of business excellence of hotel companies on performance indicators from the managerial aspect. Therefore, finally, based on the results of empirical research, we confirm the research hypothesis that there is a statistically significant impact of business excellence dimensions on business performance indicators of hotel companies, with statistically very significant quality assurance, continuous improvement and hotel value for money.

Based on the results of the research, we can single out ten questions rated with the highest rating by the hotel manager. 
Table 6: Ten most important questions from the aspect of hotel managers

\begin{tabular}{|c|l|r|}
\hline & \multicolumn{1}{|c|}{ Questions } & Average rating \\
\hline 1. & $\begin{array}{l}\text { Your hotel is characterized by the claim that the satisfaction of tourists } \\
\text { and their loyalty is a significant measure of the quality of hotel service. }\end{array}$ & 4,81 \\
\hline 2. & It is important for hotels to modernize their processes and resources. & 4,81 \\
\hline 3. & $\begin{array}{l}\text { It is characteristic of your hotel to attach great importance to the impro- } \\
\text { vement of all dimensions of the quality of hotel service (touch ability, } \\
\text { reliability, expertise and trust, friendliness, etc.). }\end{array}$ & 4,79 \\
\hline 4. & $\begin{array}{l}\text { It is typical for your hotel to take internal measures to reduce the number } \\
\text { of consumer complaints, the number of poor services / products, in order } \\
\text { to achieve greater satisfaction with the service provided. }\end{array}$ & 4,79 \\
\hline 5. & $\begin{array}{l}\text { Your hotel is characterized by attaching great importance to regular } \\
\text { maintenance of the hotel building and regular maintenance of equip- } \\
\text { ment and devices, and if necessary, worn out and damaged equipment is } \\
\text { replaced with new (carpentry, locksmith, furniture, carpets, bedding, table } \\
\text { linen, kitchen appliances and equipment, sanitary equipment, heating, air } \\
\text { conditioning, etc.). }\end{array}$ & 4,77 \\
\hline 6. & $\begin{array}{l}\text { It is characteristic of your hotel to attach great importance and a high } \\
\text { degree of legal and ethical responsibility. }\end{array}$ & 4,77 \\
\hline 7. & $\begin{array}{l}\text { Service delivery processes are continuously improved to achieve complete } \\
\text { satisfaction and increase value for guests, agencies and tour operators. }\end{array}$ & 4,72 \\
\hline 8. & $\begin{array}{l}\text { Your hotel is characterized by the use of the Internet (booking.com, } \\
\text { tripadvisor.com, travelcity.com, etc.) and other modern information tech- } \\
\text { nology as instruments to ensure quality control of hotel services. }\end{array}$ & 4,72 \\
\hline 9. & $\begin{array}{l}\text { Hotel staff have precisely written instructions (rules, procedures and / or } \\
\text { work instructions) for performing certain activities. }\end{array}$ & 4,67 \\
\hline 10. & $\begin{array}{l}\text { It is characteristic of your hotel to attach great importance to the quality } \\
\text { management system. }\end{array}$ & 4,65 \\
\hline
\end{tabular}

\section{Source: author's creation}

The highest average score was given to two questions: "Your hotel is characterized by the statement that the satisfaction of tourists and their loyalty is a significant measure of the quality of hotel service" and "It is important for hotels to modernize their processes and resources" 4.81. In third and fourth place, respectively, are issues related to the dimensions of the quality of hotel service and taking internal measures to reduce the number of consumer complaints 4.79. It can also be concluded that in these ten issues with the highest average score, there are as many as five in the field of quality assurance, which once again emphasizes the emphasis on this performance crucial in improving the business of hotel companies in Bosnia and Herzegovina. Furthermore, we can note that in these ten issues also participate issues in the field of process and resource management, and relate to the modernization of processes and resources and the application of precisely written instructions, and issues in the field of continuous improvement, which relate to taking internal measures to reduce the number of consumer complaints and the continuous improvement of the service delivery process. Participation in the ten most important issues related to the performance of business excellence was taken by one issue from the performance of social responsibility, and it refers to the attachment of great importance and a high degree of legal and ethical responsibility. 


\section{CONCLUSION AND RECOMMENDATION}

Insight into the current scientific and professional literature, various authors point to the need to create awareness of the concept of business excellence, but also to understand the importance of the performance of this concept for the improvement of hotel business. Many studies point to the need to incorporate key business excellence performance into the hotel business, emphasizing that hotel managers should strive to ensure the optimal combination of business excellence performance (hotel offer - value for money, staff education, process and resource management, quality assurance, social responsibility and continuous improvement) in order to operate more successfully.

The most significant conclusions of the empirical part of the research will be presented below:

- The survey included the views of hotel managers regarding each business excellence performance. Within each performance, we analysed a number of attributes, or claims that described business excellence. Respondents expressed a degree of agreement with each statement, which was the basis for analysing their views on the importance of each of the performances.

- When it comes to assessing the importance of business excellence performance in hotel business, managers expressed the following views: the performance of business excellence "Quality Assurance" was rated collectively with the highest average score of 4.67 , followed by "Process and Resource Management" 4.56, "Continuous Improvement" 4.55. From the point of view of the hotel manager, the performance "Hotel offer - value for money" was rated with the lowest average score of 3.68. All this led us to the conclusion that "inviolability" is more important for managers in the process of improving the business of hotel companies.

It is a notorious fact that the situation with the application of the concept of business excellence in the practice of hotel companies in $\mathrm{B} \& \mathrm{H}$ is not particularly favourable, since this issue has not been addressed at all. Although we can see progress in improving the quality of service delivery in B\&H hotels, the very concept of business excellence has not been sufficiently explored, and therefore not represented in the hotel business.

Considering the above, the conclusion is that everything points to the need for adoption and business according to the concept of business excellence, and that its application is necessary to ensure good business results, and thus achieve a competitive advantage of each hotel company. It is evident that hoteliers in B\&H have taken the path of quality, but however, they are not yet doing so systemically. 
The introduction of international standards, application and business according to the concept of business excellence, use of best practice experiences, monitoring of modern trends, is generally reduced only to the initiatives of individuals. However, this is not enough, since hoteliers today are required to excel in every segment of the business, in all performances, which requires the adoption of new forms and strategies for managing the entire business. It is notorious that Bosnian hoteliers have great prospects, but first and foremost they have to solve many problems and weaknesses, in order to improve all the performance of business excellence. By using a self-assessment of a company's own business excellence based on its performance, very good indicators of the situation can be reached, as well as conclusions about the areas of business that need to be improved.

The contribution of this research is even greater if we take into account the fact that no systematic research on this topic has been conducted so far, and the study of this research problem is not sufficiently represented in the domestic literature.

\section{REFERENCES}

1. De Souza Meira, J.V., Gadotti Dos Anjos, S., and Falaster, Ch.D., 2018. Innovation and performance in the hotel industry, Journal of Quality Assurance in Hospitality \& Tourism, pp.2-14

2. Enz, Cathy A., 2010. Hospitality Strategic Management: Concepts and Cases. 2nd Ed. New Jersy: John Wiley \& Sons, Inc.

3. Enz, K.A., 2009. Key Issuses of Concern in the Lodging Industry: What Worries Managers. Cornell University, Ithaca: The Center for Hospitality Research

4. Kandampully, Jay, A., 2007. Services management: the new paradigm in hospitality, Pearson Education, Inc., Upper Saddle River, New Jersey.

5. McKinsey Global Institute, 2019. Globalization In Transition: The Future Of Trade And Value Chains, McKinsey Global Institute, pp.1-144.

6. Mihajlović, I. And Krželj - Čolović Z., 2015. The Impact Of Globalisation On The Development Of Tourism Within Social And Economic Changes, European Scientific Journal /SPECIAL/ edition, pp. 108-121

7. Milardović, A., 1998. Poraz Europe, PanLiber, Osijek-Zagreb-Split.

8. Moutinho, L.,2005. Strateški menadžment u turizmu, Masmedia, Zagreb.

9. Niewiadomski, P., 2015. The globalisation of the hotel industry and the variety of emerging capitalisms in Central and Eastern Europe, European Scientific Journal /SPECIAL/ edition, pp. 101-121 
10. Njavro, Đ.,1999. Gospodarstvo, socijalna politika i globalizacija, Mate, Zagreb.

11. Tsai, H., Song, H., and Wong, K.F. 2015. Tourism And Hotel competitiveness Research, Journal of Travel \& Tourism Marketing, 26:5-6, pp. 522-546,

12. Turek, F., 1999. Globalizacija i globalna sigurnost, Hrvatska udruga za međunarodne studije, Varaždin.

13. Walker, J. R., 2009. Introduction to Hospitality, 5th Ed.: Person, Prentice Hall, New Jersey.

14. Yua, Y., Woo-Hee B. and Jeonglyeol Leeb, T., 2015. Critical Issues Of Globalisation In The International Hotel Industry, Current Issues in Tourism, pp. 11-25

15. Žilić, I., 2012. Poslovna izvrsnost u visokokategoriziranim hotelima u Hrvatskoj, Šibenik.

16. Zaitseva, N.A.,. Larionova, A., V. Yumatovc,. Korsunova N., and V. Dmitrieva N., 2016. Assessment of the Impact of Globalization on the Introduction of Innovative Technology Companies in the Hospitality Industry, International Journal of Environmental \& Science Education, Vol. 11, No. 14, pp. 7176-7185 
Samira Dedić

Amra Nuhanović

Jasenka Đulić

\section{ISTRAŽIVANJE VAŽNOSTI PERFORMANSI POSLOVNE IZVRSNOSTI HOTELSKIH PREDUZEĆA U VREMENU GLOBALIZACIJE I REGIONALIZACIJE}

\section{SAŽETAK}

Fokalna tačka istraživanja u ovom radu temelji se na ispitivanju i ocjenjivanju uloge $i$ značaja perfomansi poslovne izvrsnosti u hotelskoj industiji u vremenu globalizacije i regionalizacije. Istraživanje koje je sprovedeno u radu je obuhvatilo stavove hotelskih menadžera vezane za svaku performansu poslovne izvrsnosti u Bosni i Hercegovini (BiH). Notorna je činjenica, da situacija s primjenom koncepta poslovne izvrsnosti u praksi hotelskih preduzeća u BiH, nije posebno povoljna, budući da ova problematika uopšte nije obrađivana. Iako možemo vidjeti napredak po pitanju poboljšanja kvaliteta u pružanju usluga u hotelima BiH, sam pojam poslovne izvrsnosti nije dovoljno istražen, pa samim tim ni zastupljen u području hotelskog poslovanja. Uvažavajući prethodno, autori su došli do zaključka da sve upućuje na potrebu usvajanja i poslovanja prema konceptu poslovne izvrsnosti, te da je primjena istog nužna za osiguranje dobrih poslovnih rezultata, a samim tim i postizanja konkurentske prednosti svakog hotelskog preduzeća. U okviru razrade teorijskih polazišta promatranog problema korištene su metode analize i sinteze, metode indukcije i dedukcije, uz nuždu sistematskog pristupa u istraživanju. U empirijskom dijelu istraživanja korištene su statističke metode univarijatne analize (deskriptivna statistička analiza), bivarijantna analiza i multivarijantna analiza. Prikupljeni podaci obrađeni su uz pomoć SPSS Statistics 20.0

Ključne riječi: globalizacija, regionalizacija, performanse, poslovna izvrsnost, hotelska preduzeća

JEL: $F$ 66, C 19, A 12 